\title{
Connecting with First-year Engineering Students' Interest in Social Justice Issues through Ethics Lessons to Sustain Student Retention in Engineering
}

\section{Ms. Kathryn Waugaman, University of Colorado Boulder}

Katie is an undergraduate student researcher at the University of Colorado, Boulder. She is interested in why students choose to study engineering and what retention methods are successful for universities, particularly in underrepresented communities. She is a Senior in Mechanical Engineering and plans to work in renewable energy when she graduates in December.

\section{Dr. Janet Y Tsai, University of Colorado, Boulder}

Janet Y. Tsai is a researcher and instructor in the College of Engineering and Applied Science at the University of Colorado Boulder. Her research focuses on ways to encourage more students, especially women and those from nontraditional demographic groups, to pursue interests in the eld of engineering. Janet assists in recruitment and retention efforts locally, nationally, and internationally, hoping to broaden the image of engineering, science, and technology to include new forms of communication and problem solving for emerging grand challenges. A second vein of Janet's research seeks to identify the social and cultural impacts of technological choices made by engineers in the process of designing and creating new devices and systems. Her work considers the intentional and unintentional consequences of durable structures, products, architectures, and standards in engineering education, to pinpoint areas for transformative change.

\section{Dr. Malinda S Zarske, University of Colorado, Boulder}

Malinda Zarske is a faculty member with the Engineering Plus program at the University of Colorado Boulder. A former high school and middle school science and math teacher, she has advanced degrees in teaching secondary science from the Johns Hopkins University and in civil engineering from CU-Boulder. Dr. Zarske teaches undergraduate product design courses through Engineering Plus as well as STEM education courses for pre-service teachers through the CU Teach Engineering program. Additionally, she mentors graduate and undergraduate engineering Fellows who teach in local K-12 classrooms through the Integrated Teaching and Learning Program's TEAMS initiative, is on the development team for the TeachEngineering digital library, and is faculty advisor for CU-Boulder's Society of Women Engineers (SWE). Her primary research interests include the impacts of project-based service-learning on student identity, pathways and retention to and through K-12 and undergraduate engineering, teacher education and curriculum development. 


\title{
Connecting with first-year engineering students' interest in social responsibility through ethics lessons to sustain student retention in engineering
}

\begin{abstract}
The goal of this study is to identify and analyze engagement strategies. Ethics lessons from five instructors in first-year engineering projects courses will be observed and analyzed. The research questions are what are successful engagement strategies instructors and what ethical teaching outcomes does each produce?, how can these strategies begin to achieve Triggered-Feeling in their students? and how do these Engineering Ethics lessons affect students' perspectives of an engineer's role in ethical decision-making? These questions investigate the connections students can begin to form between their personal sense of social responsibility and engineering curriculums. By answering these questions, we seek a deeper understanding of how students can form meaningful connections with engineering and become more inclined to stay in the program. Data will be presented in the form of pre- and post-surveys from the students regarding the course and engineering overall and the students' impressions of the Ethics lectures.
\end{abstract}

\section{Introduction}

Many professional engineers agree that the most rewarding aspects of their jobs are seeing their ideas come to life and having a direct effect on people's everyday lives [1]. Students respond positively to messages that promote these values of engineering, yet there are low retention rates in engineering, due to students' perception of a learning environment that fails to motivate them [2]. Engineering Ethics lessons are important in the world of increasingly complex issues, as engineers with rigid, mono-cultural perspectives will not be able to see the spectrum of diverse human experiences within the contemporary complex world [3]. To overcome the hurdles that aspirational, change-making engineers face, universities must nurture a culture that produces engineers who are knowledgeable and passionate about the social justice implications of decisions made in their careers. These goals can in part be accomplished by engaging students in a first-year Ethics lesson that helps them to retain the content through interest-eliciting instructional methods.

At the University of Colorado Boulder, ABET requirement $\mathrm{F}$ is partially fulfilled in a 50-minute lecture that takes place in a first-year engineering projects course. GEEN 1400 is the primary location of ABET F objective. The objective states students must have: "An understanding of professional, ethical, legal, security and social issues and responsibilities" [5].

Student engagement plays a significant role in the academic achievement of students. In this study, however, engagement is studied in the context of student retention in engineering. Various teaching techniques can increase student engagement and allow students to connect with Engineering Ethics material at a deeper and more personal level.

Engagement can be measured through "situational interest (SI)", which defines how students connect to lesson content and either do or do not retain this content over time [4]. One model of situational interest identifies three stages of interest development: Triggered, Maintained- 
Feeling, and Maintained-Value [7]. Maintained-Feeling refers to a students' deeper understanding of content as students make profound connections to the material. This interest can develop into the third stage of SI, Maintained-Value, in which students apply concepts learned to other situations in their lives.

If students' sense of Triggered-Value increases, so may their association with an engineering education. The eventual result could be increased student retention in engineering.

This study will involve a pre-survey to students to gauge developed commitment to social responsibility, as well as students' general impression of the first-year course. This provides a framework for analyzing meaningful post-survey responses and educational outcomes of the Ethics lessons.

A post-survey will be administered to analyze the Triggered-Feeling effects of the lesson to formulate projections on effects on the students' persistence in engineering. This survey selves into content of the Ethics lessons and students' main takeaways from the lessons.

Teaching Dimensions Observation Protocol [8] observations of the 50-minute class period will help connect student engagement to particular methods and events in the lesson. Categories include engagement assessments every two minutes during a lesson.

\section{Background}

Engineering programs struggle to retain students through difficult curriculums and tedious technical courses. After four years of engineering curriculum, only $57 \%$ of students remain in engineering [9]. These low retention rates are partially due to unwelcoming environments that resist students' persistence.

Engineering lessons that effectively connect to students are likely to create lasting situational awareness impacts with students, causing them to forge stronger connections with their engineering education. Situational interest can be defined as "an immediate affective response to certain conditions and/or stimuli in the learning environment that focuses one's attention on the task, which may or may not last over time" [4]. Various studies investigate various forms of situational interest in students. Situational interest can be triggered, that is, caused by attention grabbing strategies; maintained, where students begin to form connections with the material; and become a value situational interest that persists with students after the lesson.

Situational interest can be measured in a small classroom using various "interest events" during the class session to evaluate student engagement [4]. The effects of events such as instructor lectures, small-group discussions, self-directed assignments, and group discussion can be compared to the effect on situational interest that each of these events has on students.

\section{Methods}

Research Questions 
Primary research questions of this study are: "What are successful engagement strategies instructors use, and what ethical teaching outcomes does each produce?", "How can these strategies begin to achieve Triggered-Feeling in their students?" and "How do these Engineering Ethics lessons affect students' perspectives of an engineer's role in ethical decision-making?”

Pre-survey

Pre-survey responses will be used to gauge student's interest in the projects course as a whole. This data will serve as a baseline to compare to attitudes of the projects class in general vs. the Ethics lecture. Questions will inquire about "Mastery" goals that predict interest in the course and "Work averse" topics to further illustrate students' interest in the course [6].

\section{$\underline{\text { Observation }}$}

Observation of Ethics lessons will take place five of the freshman projects Ethics lessons. These observations will be performed using "Teaching Dimensions Observation Protocol" methods ("TDOP"). TDOP is a tool used to evaluate various elements of classes, shown in Figure 1.
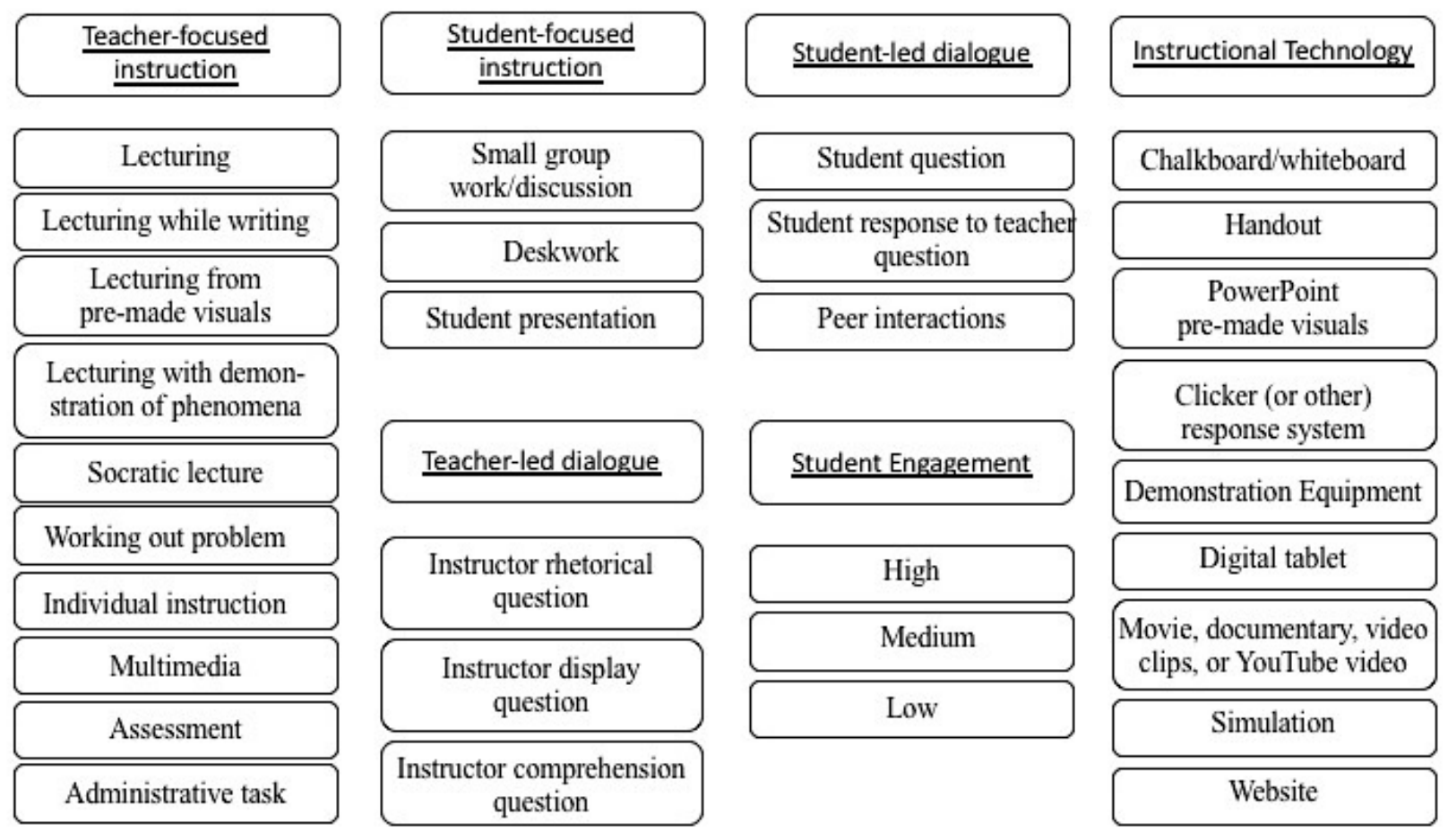

Figure 1: TDOP categories.

Two to three observers begin a TDOP session. The session is split into two-minute "intervals". During each interval, the observers identify and record observations of elements in Figure 1.

Before an actual observation session takes place, TDOP observations are "calibrated" between observers. Practice evaluation sessions require observers to individually code sample class observation videos. TDOP online software then finds inter-rater reliability statistics to compare 
the results of the observations. These comparisons are found using Cohen's kappa calculations. IRR ratings achieved by observers range from "moderate" to "very good" as shown in Table 1.

\section{Post-survey}

The post-survey investigates student opinion on the Ethics lesson and engagement events that occurred during class. In the context of engagement, student input is critical. Questions will ask about methods instructors used, events that occurred in class, and how the effects of the lesson may persist in other aspects of the students' lives (value SI). These insights will give student input to results from TDOP observations and indicate any trends missed by the researchers.

Quantitative data includes Likert-scale responses with questions that additionally inquire about student's interest in the Ethics lecture. Questions are pulled from "Interest" questions in [6].

\section{Study Limitations}

The biggest limitation in this study is the duration of the Ethics lessons. The introductory projects course sessions last only 50-minutes and there will be, at most, six different observations of classes with 20-30 students.

Additionally, much of the data is from observation-sessions. While observers make every effort to be objective, much of the observation data is a result of observer judgement. Data must also be completely de-identified to comply with IRB policy and cannot be used to compare the same student's response before and after the lecture.

In order to mediate the effects of observer subjectivity, the three observers "calibrate" observation techniques before observing as described in the TDOP Users Guide. Observers watched a sample class video and record the elements of the lectures as shown in Figure 1.

For each of the Ethics lectures, two to three observers then used the TDOP software to observe various elements and interaction of Ethics lectures. Inter-rater reliability (IRR) indices Cohn's Kappa similarity statistic. This statistic compares two observers to each other and results are shown in Table 1.

Table 1: Inter-rater reliability ratings for each observer pair.

\begin{tabular}{|l|l|l|l|l|l|l|l|}
\hline $\begin{array}{l}\text { Class } \\
\#\end{array}$ & $\begin{array}{l}\text { Observers } \\
\text { compared }\end{array}$ & $\begin{array}{l}\text { Teacher- } \\
\text { focused } \\
\text { Instr. }\end{array}$ & $\begin{array}{l}\text { Student- } \\
\text { focused } \\
\text { Instr. }\end{array}$ & $\begin{array}{l}\text { Teacher- } \\
\text { led } \\
\text { Dialogue }\end{array}$ & $\begin{array}{l}\text { Student- } \\
\text { led } \\
\text { Dialogue }\end{array}$ & Technology & $\begin{array}{l}\text { Student } \\
\text { Engagement }\end{array}$ \\
\hline 1 & 1,3 & 0.79 & 0.55 & 0.8 & 0.9 & 0.84 & 0.71 \\
\hline 2 & 1,2 & 0.5 & 0.93 & 0.65 & 0.51 & 0.85 & 0.58 \\
& 1,3 & 0.52 & 0.93 & 0.61 & 0.57 & 0.91 & 0.63 \\
\hline 3 & 2,3 & 0.86 & 0.86 & 0.71 & 0.6 & 0.88 & 0.62 \\
\hline 4 & 1,3 & 0.5 & 0.75 & 0.46 & 0.63 & 0.96 & 0.8 \\
\hline 5 & 1,3 & 0.94 & $\mathrm{n} / \mathrm{a}$ & 0.48 & 0.8 & 0.92 & 0.95 \\
\hline
\end{tabular}


Table 1 can be interpreted with the key in Table 2. In general, results fall under "Moderate" to "Very good". Technology has high IRR scores because it is simple and straight forward: it is obvious when the instructor is using a PowerPoint, movie, handout, etc. Teacher-led Instruction and Teacher-led Dialogue was the most difficult to gauge because it is often difficult to discern if a teacher is exhibiting "Socratic Lecture" or, more briefly, posing questions to the students, and other examples of ambiguity in observations.

Table 2: Inter-rater reliability score key. [10]

\begin{tabular}{ll} 
Cohen's Kappa & Degree of Agreement \\
\hline$<0.20$ & Poor \\
$0.21-0.40$ & Fair \\
$0.41-0.60$ & Moderate \\
$0.61-0.80$ & Good \\
$0.81-1.00$ & Very Good
\end{tabular}

\section{Data Analysis}

Pre-survey

After reversing the work-averse questions, responses are coded into a quantitative scale. Note that the Likert responses are assumed to be continuous. This showed how students enjoyed the lecture relative to how they enjoy the class and to find students' pre-established feelings on Engineering Ethics.

Responses from the Likert-scale questions will be scored as shown in Table 3. Scores can then be compared from class to class to gauge students' responses.

Table 3: Likert scale response scoring convention.

\begin{tabular}{ll} 
Response & Score value \\
\hline Strongly agree & 2 \\
Agree & 1 \\
Neither agree nor & 0 \\
disagree & \\
Disagree & -1 \\
Strongly disagree & -2
\end{tabular}




\section{Observation}

TDOP rater inter-reliability results ensure that observers' data is consistent. The results are used to compare how much time instructors spent using different teaching methods and other elements of the lecture. Results are visually reported and analyzed using tables and graphs [4]. General comments collected by researchers are also included as a qualitative form of data that are summarized into general "Lecture Profiles" to describe the lectures. The general format of each lecture is also shown in pie charts to illustrate dominant lecture and participation styles.

Post-survey

Quantitative (Likert-scale) post-survey data evaluates student interest in the Ethics lecture. Responses of these questions are compared to pre-survey questions that relate to the Projects course as a whole. The Likert-scale questions will be coded as shown in Table 3.

Qualitative comments are coded into categories that demonstrate students' outcomes and compared by lecture. Instructor-methods are compared to student outcomes as determined by these results and can be used to highlight successful instructor engagement methods.

\section{Results \& Discussion}

\section{Pre-survey Results}

Pre-survey question responses are shown in Figure 2 using the continuous-Likert response rating convention (Note: pre-survey data was unable to be obtained from Class 4). The questions are detailed in Table 4. These questions illustrate a strong, developed interest in the projects course. All questions, except for Question 5, receive a score above zero from students. This indicates the average response is "Strongly Agree" and "Agree". Overall, students are very interested and engaged in material and content taught in the projects courses.

The one question that shows a large discrepancy between class responses is Question 5: "I just want to do as little work as possible in this class." The responses are substantially different answers between the four classes. Class 1 overwhelmingly responded with disagreement to this question, while Classes 2 and 3 responded with neutral or agreement responses. This suggests the instructor in this course may have previously introduced ethics or social responsibility topics to the students.

In Question 2 ("I want to do as little work as possible in this class. (reversed)"), however, the distribution of responses in Classes 2, 3, and 5 switches to disagree with the negative statement. This is curious because the questions are virtually the same and even have the same "negative connotation." While the scope of this study does not investigate the context to these responses, it can be concluded that Classes 2, 3, and 4 may have a stronger sense of work avoidance than Class 1 , though this may be skewed by the phrasing of the question. 


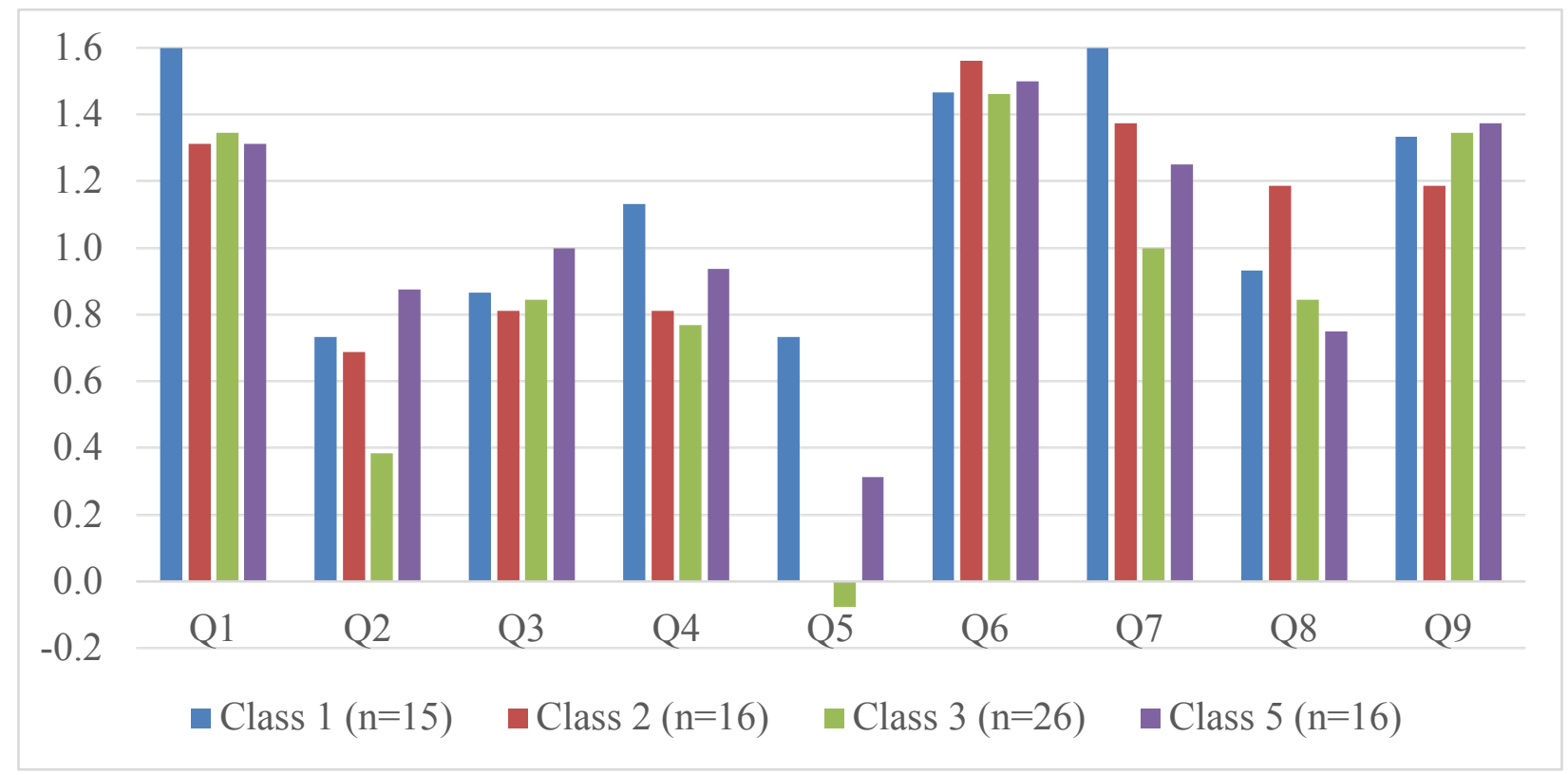

Figure 2: Pre-survey results by class.

Table 4: Questions that correlate with Figure 2. Note that Q2 and Q5 are reversed: "positive" responses reflect disagreement with statement to maintain consistency in Figure 2.

\begin{tabular}{|c|c|}
\hline \# & Question \\
\hline 1 & I want to learn as much as possible in this class. \\
\hline 2 & I want to do as little work as possible in this class. (REVERSED) \\
\hline 3 & $\begin{array}{l}\text { In a class like this, I prefer course material that really challenges me so I } \\
\text { can learn new things. }\end{array}$ \\
\hline 4 & $\begin{array}{l}\text { The most important thing for me in this course is trying to understand the } \\
\text { content as thoroughly as possible. }\end{array}$ \\
\hline 5 & $\begin{array}{l}\text { I just want to do as much as I have to in order to get by in this class. } \\
\text { (REVERSED) }\end{array}$ \\
\hline 6 & I like it best when something I learn makes me want to find out more. \\
\hline 7 & I think what we are learning in this course is important. \\
\hline 8 & Understanding Engineering Ethics is important to me. \\
\hline 9 & $\begin{array}{l}\text { In a class like this, I prefer course material that arouses my curiosity, even } \\
\text { if it is difficult to learn. }\end{array}$ \\
\hline
\end{tabular}




\section{Observation Results}

The TDOP observations revealed that Ethics lectures had extremely high engagement from students. Classes maintained the highest engagement scores for almost the entire lecture. Students were engaged in lectures and discussions and remained engaged in the lesson material for the duration of the lectures.

Within the TDOP observation software, observers are allowed to leave comments about the class. These comments are paraphrased in the following lecture profiles to introduce the format of each Ethics lecture. A summary of these descriptions can be found in 
Table 5.

Class 1:

Instructor takes a Socratic approach to the lesson and had less lecturing and more group discussion. He passes out a case study to students to read silently or out loud in small groups. The case study is about a group of engineers and managers who had the task of deciding whether or not to race a formula F1 car. The case study described a tense, highstakes situation in which engineers were unsure of the physical limitations of the motor of the F1 engine under certain temperatures and offered many costs (in dollars, sponsorship losses, etc.) involved in pulling out of the race or driving.

The class alternates between students discussing in groups of 4-6 and writing thoughts, calculations, etc. down on posters. Instructor brings the class together and runs through simple cost analyses on the overhead projector in Excel.

Towards the end of the class period, Instructor has students take a vote on whether to race or not-race. He then tells the class that the scenario was equivalent to the Challenger scenarios in which astronauts were killed because management overrode engineers' advice to not launch the space shuttle. Lecture wraps up with some takeaway messages and "lessons learned" about the situation.

\section{Class 2:}

Instructor conducts lecture style class for the first half. Begins by introducing ethical codes, engineering creed, etc.

Instructor then goes over the story of Flint, MI and the water crisis. She walks through the context of the story, a video of scientific explanations of lead poisoning, and then goes over the multitude of poor decisions that were made by management, engineers, and government officials.

For the last part of the lecture, Instructor passed out different case studies to each of the 5 tables. Each table shared out on the most ethical course of action. Lecture wraps up with a conclusion discussion about discussion of ethics code. 


\section{Class 3:}

Instructor 3 uses a PowerPoint and starts with an introduction to ethics, including a definition of "ethics" and "morals" and goes over ABET ethics codes. She then asks students to discuss in groups how ethics apply to their projects and then to write down their own definition of ethics.

Instructor 3 then begins to introduce the Challenger example still using the PowerPoint. She starts a class discussion about the Challenger tragedy by asking for students' thoughts. Most of discussion revolves around how the engineers are involved in the decision and outcome of the Challenger. Students also talk about other ethical incidents in the news recently.

\section{Class 4:}

Instructor uses Challenger example to portray a dramatic, historical incidence in which ethical decisions were not made. Begins by showing a PowerPoint presentation building up to the accident. Asks students questions like: "What would you do? There's no right answer."

Plays a dramatic video that re-enacts the meeting with engineers and management regarding the shuttle takeoff and insufficient data. The video is suspenseful and about 15 minutes long. When it is over, instructor asks students for feedback and starts a discussion, eventually leading into a Code of Ethics PowerPoint slide.

A TA passes out a 12-page handout with various codes of ethics and introduces assignment. Instructor goes over other examples of newsworthy ethical and engineering failures, as well as strategies to evaluate ethical decisions.

\section{Class 5:}

Instructor 5 introduces ethics with a case study that shows results from students' preassignment and survey. Instructor discusses ethics definitions, ethics and engineering, shares some famous quotes, a code of ethics, and some news headlines.

Instructor 5 then talks about the collapse of the Florida bridge in 2018. There is a class discussion about the choices of the engineers and construction firm management that led to the collapse. Students discuss in small groups what they think should have been done. Instructor then relates discussion back to ethics code, asking provoking questions about the difference between personal and professional ethics. Class ends with a brief discussion of some short case studies. 
Table 5: Qualitative summary of Ethics lectures from TDOP observation comments.

\begin{tabular}{|l|r|r|}
\hline Instructor & Class "format(s)" & Case Study(s) Presented (if any) \\
\hline 1 & $\begin{array}{l}\text { - } \\
\text { Small group work }\end{array}$ & $\begin{array}{l}\text { Challenger tragedy (though } \\
\text { "disguised" as F1 scenario) }\end{array}$ \\
\hline 2 & $\begin{array}{l}\text { - } \text { Lecture } \\
\text { Small group work }\end{array}$ & - Flint Water Crisis \\
\hline 3 & \begin{tabular}{l} 
- $\begin{array}{l}\text { Secture } \\
\text { - Class discussion }\end{array}$ \\
\hline 4
\end{tabular} & - Challenger tragedy \\
\hline 5 & $\begin{array}{l}\text { Class and small group } \\
\text { discussion }\end{array}$ & - Challenger tragedy \\
\hline
\end{tabular}

The observation software provides results of the lectures as broken down categorically. Figure 3 shows an overview of the lecture styles. The y-axis shows the percentage of class time spent using a particular class style. Summaries of these categories can be seen in Figure 1. Note that the bars to not add up to $100 \%$ because instructors could either use two lecture styles at once or switch between styles within an interval (for example, lecturing interspersed with class or small group discussions).

These results support qualitative profiles of each lecture that are previously described. Instructor 1 , for example, uses a broad range of methods in the lecture. Instructor 4 , however, uses almost entirely teacher-led and -focused lecture styles.

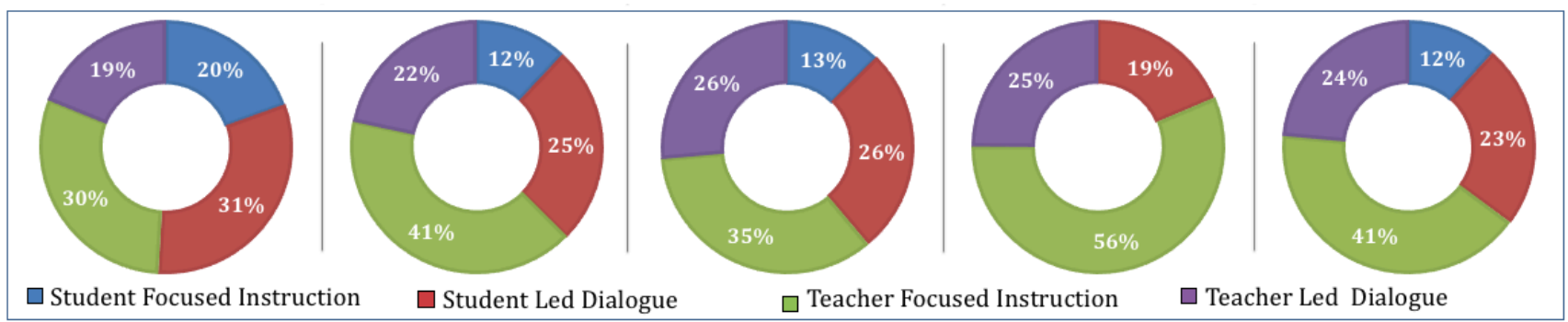

Figure 3: Breakdown of class format.

The results shown in Figure 3 explain some of the differences between classes in the following section.

\section{Post-survey Results}

Post-survey results showed numerous differences between classes as well as surprising similarities. Quantitative and qualitative data shows students' attitudes across all sections of the course. 


\section{Student Outcomes (Qualitative)}

One of the most telling post-survey questions asked, "What is one thing you'll remember from the Ethics Lecture?" While it may have been more useful to get comprehensive reflections from students, the prompt asks for a brief response to increase the likelihood of the survey participation and completion. Figure 4 shows the variety of different takeaways students reported from the various Ethics lecture. The results of the survey question show trends between the different content focuses of each lecture. For example, two of the classes that featured the Challenger tragedy (Instructors 1 and 4) show that the example stuck with students after the lecture, as the "Case Study" category mostly refers to the in-class examples presented.

\begin{tabular}{|c|c|c|c|c|c|}
\hline Rank & Class 1 & Class 2 & Class 3 & Class 4 & Class 5 \\
\hline 1 & $\begin{array}{l}\text { Decision } \\
\text { Making: } 61 \%\end{array}$ & $\begin{array}{l}\text { Ethics vs. } \\
\text { Law/Employer: } \\
36 \%\end{array}$ & $\begin{array}{l}\text { Class Case } \\
\text { Study: } 44 \%\end{array}$ & $\begin{array}{l}\text { Class Case } \\
\text { Study: } 38 \%\end{array}$ & $\begin{array}{l}\text { Class Case } \\
\text { Study: } 38 \%\end{array}$ \\
\hline 2 & $\begin{array}{l}\text { Class Case } \\
\text { Study: } 39 \%\end{array}$ & $\begin{array}{l}\text { Ethics Codes \& } \\
\text { Morals: } 21 \%\end{array}$ & $\begin{array}{l}\text { An Engineer's } \\
\text { Role in Ethics: } \\
21 \%\end{array}$ & $\begin{array}{l}\text { Ethics vs. } \\
\text { Law/Employer: } \\
33 \%\end{array}$ & $\begin{array}{l}\text { An } \\
\text { Engineer's } \\
\text { Role in } \\
\text { Ethics: } 31 \%\end{array}$ \\
\hline 3 & (none) & $\begin{array}{l}\text { Class Case } \\
\text { Study: } 14 \%\end{array}$ & $\begin{array}{l}\text { Ethics vs. } \\
\text { Law/Employer: } \\
13 \%\end{array}$ & $\begin{array}{l}\text { Ethics Codes \& } \\
\text { Morals: } 22 \%\end{array}$ & $\begin{array}{l}\text { Decision } \\
\text { Making: } 13 \%\end{array}$ \\
\hline
\end{tabular}

Figure 4: Student outcomes from post-survey.

A breakdown of participants' responses is shown in Figure 4. Responses from this question were coded into various responses as shown in Table 6 . The results of the survey question show trends between the different content focuses of each lecture. Two of the top responses from students were "Decision Making" and "Class Case Study."

Table 6: Post-survey student-outcome comments summary.

\begin{tabular}{|l|c|}
\hline Legend Entry & Example Student Responses \\
\hline Ethics Codes \& Morals & $\begin{array}{l}\text { - "We should follow the Code of Conduct and the Moral Tests } \\
\text { to determine what we should do" } \\
\text { - "Learning moral perspectives." } \\
\text { - "To always keep my personal integrity at the highest } \\
\text { standard even when it is a detriment to my company or } \\
\text { another's." }\end{array}$ \\
\hline Decision Making & $\begin{array}{l}\text { - "I'm not sure that this lecture was about ethics, I learned } \\
\text { mostly about decision making." }\end{array}$ \\
\hline
\end{tabular}




\begin{tabular}{|c|c|}
\hline & $\begin{array}{l}\text { - "You need to take into account more than one thing, and } \\
\text { look beyond the given information" } \\
\text { - "How you can manipulate data" }\end{array}$ \\
\hline $\begin{array}{l}\text { Ethics vs. } \\
\text { Legality/Employer }\end{array}$ & $\begin{array}{l}\text { - "Just following the law doesn't make things completely } \\
\text { ethical" } \\
\text { - "There are engineering hats and management hats" }\end{array}$ \\
\hline $\begin{array}{l}\text { A Specific Example or } \\
\text { Case Study }\end{array}$ & $\begin{array}{l}\text { - "I liked the real-world examples we talked about to make us } \\
\text { realize it was important" } \\
\text { - "I launched the Challenger." }\end{array}$ \\
\hline Safety & $\begin{array}{l}\text { - "How responsible we are for human life" } \\
\text { - "We should hold safety paramount." }\end{array}$ \\
\hline $\begin{array}{l}\text { Engineers and their } \\
\text { roles in ethics }\end{array}$ & $\begin{array}{l}\text { - "Accounting the different factors that involve making a } \\
\text { - "Tecision as an engineer" } \\
\text { - "That it is our RESPONSIBILITY to be ethical" } \\
\text { - "It was a lecture think really perthing is unethical." } \\
\text { going to need in the future" }\end{array}$ \\
\hline
\end{tabular}

In Class 1, 61\% of the class responded with Decision Making as their largest takeaway. This correlates with data shown in Figure 3: Class 1 has the largest proportion of class time dedicated to Student Focused Instruction and Student Led Dialogue. During small-group work, peer to peer interactions, and Socratic style class discussions, students learn best how to make decisions. Class 1 specifically required students to discuss various options, statistics, and context to the ethical dilemmas posed to them. These activities instilled students with a strong sense of the importance of making decisions with careful thought.

Three of the classes were particularly successful in portraying a case study to the students. Classes 3, 4, and 5 had 38-44\% of students report Case Studies as takeaways from the class. Two of these classes studied the Challenger Space Shuttle tragedy and one of them looked at the Florida Bridge collapse that occurred at FIU Sweetwater University in March of 2018. Each of these examples had different strengths and how they impacted students.

The Challenger Space Shuttle narrative has strengths in its historical significance. Class 5 featured a dramatic film on the event and how engineers and managers were at odds about the decision to launch. The impact of the event was striking to students as well. The Challenger carried a historic crew of astronauts and even had the first teacher intended to go to space on board. The launch was approved under intense pressure from the media and government, though in the face of missing data that would predict success. Students seemed interested in the gravity of the situation and surprised that such a reckless decision would be made. In Class 1, the scenario was "masked" by another, parallel situation in which a company was deciding whether or not to race a Formula I car. Before the instructor revealed that the scenario was analogous to the Challenger event, more than half of the students voted to "race the car." This shows that 
while students are shocked by the final event, it is difficult to make the right decision under pressure and other stressful conditions.

The other two case studies featured more recent events that had more contemporary value to the events. The Florida Bridge Collapse and Flint Water Crisis lacked the drama and historical weight of the Challenger tragedy but brought more relatability to the students and class discussions. The Bridge Collapse, for example, had happened less than seven days before the lecture. Students had heard about it in the news and were aware of the situation. The class was successful in connecting the event to engineers and ethical decision-making skills. In the bridge collapse event, engineers were aware of cracks in the bridge that may or may not affect the integrity of the structure and likely did not take proper action to mediate these dangers in the installation of the bridge. In the Flint Water Crisis, an engineer was aware that water in the city was not being treated with anti-corrosion agent and did not act to fix the issue. These issues impacted students because they could see themselves as an engineer working for a construction company like the company involved in the bridge collapse, or an engineer working for a government agency like the one in the Flint Water Crisis. Conversation also wandered to other mainstream ethical dilemmas and events, such as a self-driving car striking and killing someone in Arizona.

\section{Quantitative Results}

Post-survey Likert scale responses from students are shown in Table 7. These questions delved into students' takeaways on the Ethics lecture and outcomes related to ABET requirements.

Table 7: Post-survey questions.

\begin{tabular}{l|l}
$\#$ & Question \\
\hline 1 & I think what we learned in the Ethics Lecture is important. \\
2 & Understanding Engineering Ethics is important to me. \\
3 & I think what we studied in the Ethics Lecture is useful for me to know. \\
4 & To be honest, I just don't find Engineering Ethics interesting. \\
5 & I think the field of Engineering Ethics is important. \\
6 & I find the content of the Ethics Lecture personally meaningful. \\
7 & I think this class is interesting. \\
8 & I see how I can apply what we learned in the Ethics Lecture to real life.
\end{tabular}

Results from these questions show small differences bet

ween classes. The range of standard deviation in each question is $0.11-0.24$, indicating relative agreement across all classes. Notice that Question 4 is "reversed": Agree and disagree responses were reversed in results to maintain "desired" responses from each of the questions.

There are also some differences to note, however. For example, Class 2 receives the highest score for every question except for Q7. These students demonstrate the highest interest and positive experiences from the Ethics lecture, which may be a result of the particular case study (Flint Water Crisis) or classroom style of the instructor (Figure 3). 


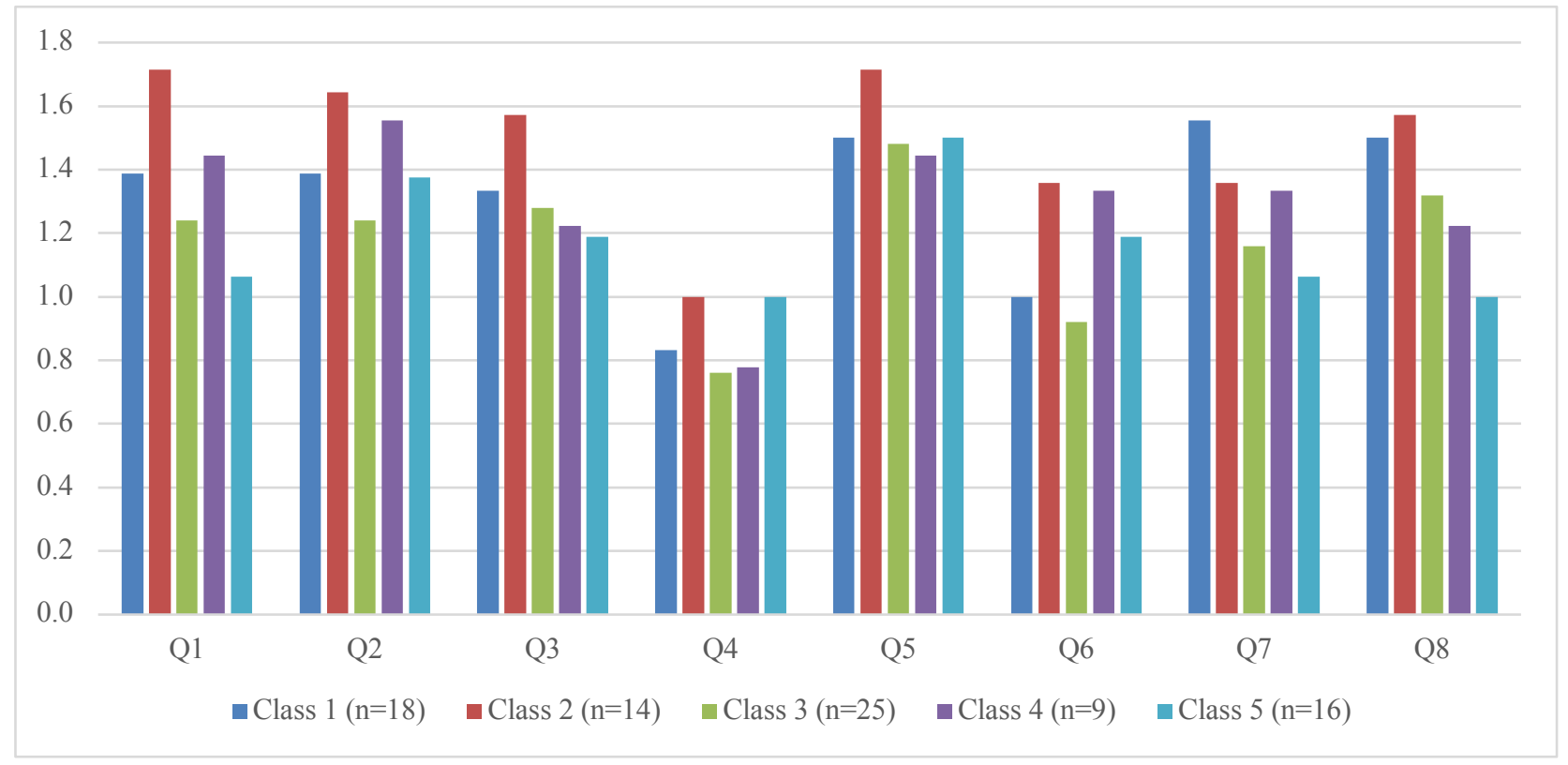

Figure 5: Post-survey results by class.

These survey responses show an overwhelming interest on the topic of Engineering Ethics after the lecture. One question was repeated from the pre-survey in the post survey: "Understanding Engineering Ethics is important to me." A comparison of responses is shown in Table 8.

Table 8: Pre- and post-survey results for the question, "Understanding Engineering Ethics is important to me."

\begin{tabular}{|c|c|c|c|c|c|c|c|c|c|c|c|c|c|}
\hline & 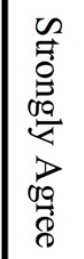 & 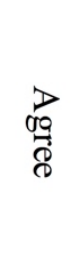 & 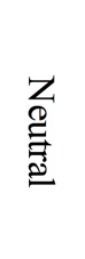 & 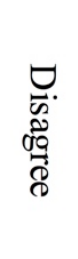 & 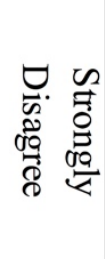 & 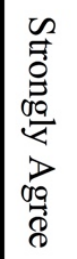 & $\underset{80}{\stackrel{80}{8}}$ & $\begin{array}{l}Z \\
\mathbb{Q} \\
\stackrel{\Xi}{0} \\
\tilde{\Xi}\end{array}$ & 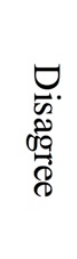 & 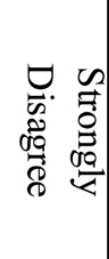 & 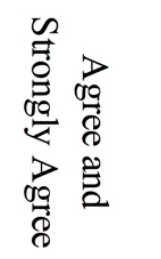 & 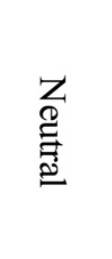 & 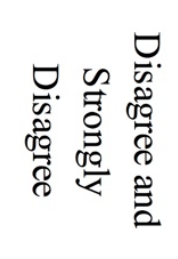 \\
\hline & $22 \%$ & $59 \%$ & $11 \%$ & $5 \%$ & $\begin{array}{l}030 \\
0\end{array}$ & 16 & 43 & & & & $80.9 \%$ & $11.0 \%$ & \\
\hline ost-survey & $48 \%$ & $45 \%$ & $7 \%$ & $0 \%$ & \% $0 \%$ & 39 & 37 & 6 & & 0 & $92.7 \%$ & $7.3 \%$ & \\
\hline
\end{tabular}

These responses show a dramatic increase in the percentage of students who think that Engineering Ethics is important for them to learn. Before the lecture, $80.9 \%$ thought that the topic is important and afterwards, $92.7 \%$ of the students agreed with the statement. This jump is substantial, especially considering that $48 \%$ of students "Strongly Agreed" with the statement, up from $22 \%$ before the Ethics lecture.

Additional statistics from these lessons show that the lectures are very popular. Students responses to the question, "Which lecture has been your favorite so far?" and $61 \%$ of responses listed their section's Ethics lecture. This is hugely significant and successful and surprising, as students in a projects course have lectures on prototyping, manufacturing, and other "cool" 
hands-on topics. For a large group of mostly 18-19 year-olds to show overwhelming interest in Engineering Ethics is a victory for the instructors.

\section{Conclusions}

This small study on ethics in a first-year engineering projects course provides insights to instructors teaching the courses and leaves room for future exploration. One overall, broad takeaway is that the Ethics lectures are popular and successful. The case study theme and layout of the lectures captivates students' interest and they are often able to make connections from the major event to their own career as an Engineer.

These Ethics lectures satisfy teacher requirements by completing ABET Criterion F [5]. Students prove their ability to consider ethical considerations related to legality and professional dilemmas through class discussions and survey results. Students also, however, can learn important decision-making strategies when it comes to ethics through activities in the Ethics lessons. Instructors have the ability to tailor their lesson plans to mainly satisfy ABET requirements, or to expand on students' skills related to ethics.

This study leaves many questions that can be built on further in the topic of Engineering Ethics in a young, first-year student class. The scope of the research could be expanded to follow students through college and gauge the long-term effects of the Ethics lectures. Ideally, content learned in the Ethics lecture would stick with the students and develop into Maintained SI or even Value SI. How students apply the lessons learned in the lecture to dilemmas such as cheating on assignments or workplace situations is another long-term aspect of student's retention of Ethical values.

\section{References}

[1] Committee on Public Understanding of Engineering Messages, "Changing the Conversation: Messages for Improving Public Understanding of Engineering," The National Academics of Science Engineering Medicine, 2008.

[2] American Society for Engineering Education, "Going the Distance: Best Practices and Strategies for Retaining Engineering, Engineering Technology and Computing Students," Aug. 2012.

[3] M. G. Prasad, "The role of cultural diversity in enhancing engineering education," Stevens Institute of Technology, 2007.

[4] J. I. Rotgans and H. G. Schmidt, "Situational interest and academic achievement in the active-learning classroom,” Learn. Instr., vol. 21, no. 1, pp. 58-67, Feb. 2011.

[5] ABET, “Criteria for Accrediting Computing Programs, 2017-2018." Criteria for Accrediting Computing Programs, 2017-2018 ABET, www.abet.org/accreditation/accreditationcriteria/criteria-for-accrediting-computing-programs-2017-2018/\#outcomes. 
[6] Harackiewicz, J.M.; Tauer, John M.; Carter, Suzanne M.; Elliot, Andrew J., "Short-Term and Long-Term Consequences of Achievement Goals: Predicting Interest and Performance Over Time," Journal of Educational Psychology, Vol. 92, no. 2, pp 316-330, 2000.

[7] L. Linnenbrink-Garcia et al., "Measuring Situational Interest in Academic Domains," Educ. Psychol. Meas., vol. 70, no. 4, pp. 647-671, Aug. 2010.

[8] Teaching Dimensions Observation Protocol (TDOP) [Scholarly project]. (2014, August). In Teaching Dimensions Observation Protocol (TDOP). Retrieved February 2, 2018, from http://tdop.wceruw.org/Document/TDOP-2.1-Users-Guide.pdf

[9] Ohland, Matthew W.; Sheppard, Sheri D.; Lichtenstein, Gary; Eris, Ozgur; Chachra, Debbie; Layton, Richard A., "Persistence, Engagement, and Migration in Engineering Programs" Mechanical Engineering (2008) Web 1 Jan. 2012.

[10] Landis, J. R., \& Koch, G. G., “The Measurement of Observer Agreement for Categorical Data," Biometrics, vol. 33, no. 1, pp. 159-174, Mar. 1977.

\section{Appendix A: Full pre-surveys}

\section{Instructor 1}

\begin{tabular}{|c|c|c|c|c|c|c|c|}
\hline \# & Question & $\begin{array}{l}\text { Strongly } \\
\text { Agree }\end{array}$ & Agree & Neutral & Disagree & $\begin{array}{l}\text { Strongly } \\
\text { Disagree }\end{array}$ & Total \\
\hline 1 & $\begin{array}{l}\text { I want to learn as much as } \\
\text { possible in this class. }\end{array}$ & 9 & 6 & 0 & 0 & 0 & 15 \\
\hline 2 & $\begin{array}{l}\text { I want to do as little work as } \\
\text { possible in this class. }\end{array}$ & 0 & 1 & 5 & 6 & 3 & 15 \\
\hline 3 & $\begin{array}{l}\text { In a class like this, I prefer } \\
\text { course material that really } \\
\text { challenges me so I can learn } \\
\text { new things. }\end{array}$ & 1 & 11 & 3 & 0 & 0 & 15 \\
\hline 4 & $\begin{array}{l}\text { The most important thing for } \\
\text { me in this course is trying to } \\
\text { understand the content as } \\
\text { thoroughly as possible. }\end{array}$ & 3 & 11 & 1 & 0 & 0 & 15 \\
\hline 5 & $\begin{array}{l}\text { I just want to do as much as I } \\
\text { have to in order to get by in this } \\
\text { class. }\end{array}$ & 0 & 1 & 4 & 8 & 2 & 15 \\
\hline 6 & $\begin{array}{l}\text { I like it best when something I } \\
\text { learn makes me want to find out } \\
\text { more. }\end{array}$ & 7 & 8 & 0 & 0 & 0 & 15 \\
\hline 7 & $\begin{array}{l}\text { I think what we are learning in } \\
\text { this course is important. }\end{array}$ & 10 & 4 & 1 & 0 & 0 & 15 \\
\hline
\end{tabular}




$8 \begin{aligned} & \begin{array}{l}\text { Understanding Engineering } \\ \text { Ethics is important to me. }\end{array} \\ & 9\end{aligned} \quad \begin{aligned} & \text { In a class like this, I prefer } \\ & \begin{array}{l}\text { course material that arouses my } \\ \text { curiosity, even if it is difficult } \\ \text { to learn. }\end{array}\end{aligned}$

\section{Instructor 2}

\begin{tabular}{|c|c|c|c|c|c|c|c|}
\hline \# & Question & $\begin{array}{l}\text { Strongly } \\
\text { Agree }\end{array}$ & Agree & Neutral & Disagree & $\begin{array}{l}\text { Strongly } \\
\text { Disagree }\end{array}$ & Total \\
\hline 1 & $\begin{array}{l}\text { I want to learn as much as } \\
\text { possible in this class. }\end{array}$ & 6 & 9 & 1 & 0 & 0 & 16 \\
\hline 2 & $\begin{array}{l}\text { I want to do as little work as } \\
\text { possible in this class. }\end{array}$ & 0 & 2 & 4 & 7 & 3 & 16 \\
\hline 3 & $\begin{array}{l}\text { In a class like this, I prefer } \\
\text { course material that really } \\
\text { challenges me so I can learn } \\
\text { new things. }\end{array}$ & 2 & 9 & 5 & 0 & 0 & 16 \\
\hline 4 & $\begin{array}{l}\text { The most important thing for } \\
\text { me in this course is trying to } \\
\text { understand the content as } \\
\text { thoroughly as possible. }\end{array}$ & 2 & 10 & 3 & 1 & 0 & 16 \\
\hline 5 & $\begin{array}{l}\text { I just want to do as much as I } \\
\text { have to in order to get by in this } \\
\text { class. }\end{array}$ & 0 & 6 & 5 & 4 & 1 & 16 \\
\hline 6 & $\begin{array}{l}\text { I like it best when something I } \\
\text { learn makes me want to find out } \\
\text { more. }\end{array}$ & 10 & 5 & 1 & 0 & 0 & 16 \\
\hline 7 & $\begin{array}{l}\text { I think what we are learning in } \\
\text { this course is important. }\end{array}$ & 7 & 8 & 1 & 0 & 0 & 16 \\
\hline 8 & $\begin{array}{l}\text { Understanding Engineering } \\
\text { Ethics is important to me. }\end{array}$ & 5 & 9 & 2 & 0 & 0 & 16 \\
\hline 9 & $\begin{array}{l}\text { In a class like this, I prefer } \\
\text { course material that arouses my } \\
\text { curiosity, even if it is difficult } \\
\text { to learn. }\end{array}$ & 6 & 7 & 3 & 0 & 0 & 16 \\
\hline
\end{tabular}




\begin{tabular}{|c|c|c|c|c|c|c|c|}
\hline$\#$ & Question & $\begin{array}{l}\text { Strongly } \\
\text { Agree }\end{array}$ & Agree & Neutral & Disagree & $\begin{array}{l}\text { Strongly } \\
\text { Disagree }\end{array}$ & Total \\
\hline 1 & $\begin{array}{l}\text { I want to learn as much as } \\
\text { possible in this class. }\end{array}$ & 12 & 11 & 3 & 0 & 0 & 26 \\
\hline 2 & $\begin{array}{l}\text { I want to do as little work as } \\
\text { possible in this class. }\end{array}$ & 0 & 5 & 8 & 11 & 2 & 26 \\
\hline 3 & $\begin{array}{l}\text { In a class like this, I prefer } \\
\text { course material that really } \\
\text { challenges me so I can learn } \\
\text { new things. }\end{array}$ & 4 & 16 & 4 & 2 & 0 & 26 \\
\hline 4 & $\begin{array}{l}\text { The most important thing for } \\
\text { me in this course is trying to } \\
\text { understand the content as } \\
\text { thoroughly as possible. }\end{array}$ & 5 & 13 & 5 & 3 & 0 & 26 \\
\hline 5 & $\begin{array}{l}\text { I just want to do as much as I } \\
\text { have to in order to get by in this } \\
\text { class. }\end{array}$ & 2 & 10 & 4 & 8 & 2 & 26 \\
\hline 6 & $\begin{array}{l}\text { I like it best when something I } \\
\text { learn makes me want to find out } \\
\text { more. }\end{array}$ & 13 & 12 & 1 & 0 & 0 & 26 \\
\hline 7 & $\begin{array}{l}\text { I think what we are learning in } \\
\text { this course is important. }\end{array}$ & 7 & 15 & 2 & 1 & 1 & 26 \\
\hline 8 & $\begin{array}{l}\text { Understanding Engineering } \\
\text { Ethics is important to me. }\end{array}$ & 4 & 17 & 3 & 1 & 1 & 26 \\
\hline 9 & $\begin{array}{l}\text { In a class like this, I prefer } \\
\text { course material that arouses my } \\
\text { curiosity, even if it is difficult } \\
\text { to learn. }\end{array}$ & 10 & 15 & 1 & 0 & 0 & 26 \\
\hline
\end{tabular}

\section{Instructor 5}

\begin{tabular}{|c|c|c|c|c|c|c|c|}
\hline \# & Question & $\begin{array}{l}\text { Strongly } \\
\text { Agree }\end{array}$ & Agree & Neutral & Disagree & $\begin{array}{l}\text { Strongly } \\
\text { Disagree }\end{array}$ & Total \\
\hline 1 & $\begin{array}{l}\text { I want to learn as much as } \\
\text { possible in this class. }\end{array}$ & 7 & 7 & 2 & 0 & 0 & 16 \\
\hline 2 & $\begin{array}{l}\text { I want to do as little work as } \\
\text { possible in this class. }\end{array}$ & 0 & 2 & 3 & 6 & 5 & 16 \\
\hline 3 & $\begin{array}{l}\text { In a class like this, I prefer } \\
\text { course material that really } \\
\text { challenges me so I can learn } \\
\text { new things. }\end{array}$ & 3 & 11 & 1 & 1 & 0 & 16 \\
\hline
\end{tabular}




\begin{tabular}{|c|c|c|c|c|c|c|}
\hline 4 & $\begin{array}{l}\text { The most important thing for } \\
\text { me in this course is trying to } \\
\text { understand the content as } \\
\text { thoroughly as possible. }\end{array}$ & 4 & 8 & 3 & 1 & 0 \\
\hline 5 & $\begin{array}{l}\text { I just want to do as much as I } \\
\text { have to in order to get by in this } \\
\text { class. }\end{array}$ & 1 & 3 & 6 & 2 & 4 \\
\hline 6 & $\begin{array}{l}\text { I like it best when something I } \\
\text { learn makes me want to find out } \\
\text { more. }\end{array}$ & 8 & 8 & 0 & 0 & 0 \\
\hline 7 & $\begin{array}{l}\text { I think what we are learning in } \\
\text { this course is important. }\end{array}$ & 8 & 6 & 0 & 2 & 0 \\
\hline 8 & $\begin{array}{l}\text { Understanding Engineering } \\
\text { Ethics is important to me. }\end{array}$ & 4 & 7 & 3 & 1 & 1 \\
\hline 9 & $\begin{array}{l}\text { In a class like this, I prefer } \\
\text { course material that arouses my } \\
\text { curiosity, even if it is difficult } \\
\text { to learn. }\end{array}$ & 7 & 8 & 1 & 0 & 0 \\
\hline
\end{tabular}

\section{Appendix B: Full post-surveys}

Instructor 1

\begin{tabular}{|c|c|c|c|c|c|c|c|}
\hline \# & Question & $\begin{array}{c}\text { Strongly } \\
\text { Agree }\end{array}$ & Agree & Neutral & Disagree & $\begin{array}{l}\text { Strongly } \\
\text { Disagree }\end{array}$ & Total \\
\hline 1 & $\begin{array}{l}\text { I think what we learned in the } \\
\text { Ethics Lecture is important. }\end{array}$ & 9 & 7 & 2 & 0 & 0 & 18 \\
\hline 2 & $\begin{array}{l}\text { Understanding Engineering } \\
\text { Ethics is important to me. }\end{array}$ & 8 & 9 & 1 & 0 & 0 & 18 \\
\hline 3 & $\begin{array}{l}\text { I think what we studied in the } \\
\text { Ethics Lecture is useful for me to } \\
\text { know. }\end{array}$ & 8 & 8 & 2 & 0 & 0 & 18 \\
\hline 4 & $\begin{array}{l}\text { To be honest, I just don't find } \\
\text { Engineering Ethics interesting. } \\
\text { (reversed) }\end{array}$ & 1 & 1 & 3 & 8 & 5 & 18 \\
\hline 5 & $\begin{array}{l}\text { I think the field of Engineering } \\
\text { Ethics is important. }\end{array}$ & 10 & 7 & 1 & 0 & 0 & 18 \\
\hline 6 & $\begin{array}{l}\text { I find the content of the Ethics } \\
\text { Lecture personally meaningful. }\end{array}$ & 5 & 10 & 1 & 2 & 0 & 18 \\
\hline 7 & I think this class is interesting. & 11 & 6 & 1 & 0 & 0 & 18 \\
\hline
\end{tabular}


8 I see how I can apply what we real life.

\begin{tabular}{|c|c|c|c|c|c|c|c|}
\hline \# & Question & $\begin{array}{l}\text { Strongly } \\
\text { Agree }\end{array}$ & Agree & Neutral & Disagree & $\begin{array}{l}\text { Strongly } \\
\text { Disagree }\end{array}$ & Total \\
\hline 1 & $\begin{array}{l}\text { I think what we learned in the } \\
\text { Ethics Lecture is important. }\end{array}$ & 10 & 4 & 0 & 0 & 0 & 14 \\
\hline 2 & $\begin{array}{l}\text { Understanding Engineering } \\
\text { Ethics is important to me. }\end{array}$ & 9 & 5 & 0 & 0 & 0 & 14 \\
\hline 3 & $\begin{array}{l}\text { I think what we studied in the } \\
\text { Ethics Lecture is useful for me to } \\
\text { know. }\end{array}$ & 8 & 6 & 0 & 0 & 0 & 14 \\
\hline 4 & $\begin{array}{l}\text { To be honest, I just don't find } \\
\text { Engineering Ethics interesting. } \\
\text { (reversed) }\end{array}$ & 0 & 0 & 2 & 10 & 2 & 14 \\
\hline 5 & $\begin{array}{l}\text { I think the field of Engineering } \\
\text { Ethics is important. }\end{array}$ & 10 & 4 & 0 & 0 & 0 & 14 \\
\hline 6 & $\begin{array}{l}\text { I find the content of the Ethics } \\
\text { Lecture personally meaningful. }\end{array}$ & 5 & 9 & 0 & 0 & 0 & 14 \\
\hline 7 & I think this class is interesting. & 6 & 7 & 1 & 0 & 0 & 14 \\
\hline 8 & $\begin{array}{l}\text { I see how I can apply what we } \\
\text { learned in the Ethics Lecture to } \\
\text { real life. }\end{array}$ & 9 & 4 & 1 & 0 & 0 & 14 \\
\hline
\end{tabular}

\section{Instructor 3}

\begin{tabular}{|c|c|c|c|c|c|c|c|}
\hline \# & Question & $\begin{array}{l}\text { Strongly } \\
\text { Agree }\end{array}$ & Agree & Neutral & Disagree & $\begin{array}{l}\text { Strongly } \\
\text { Disagree }\end{array}$ & Total \\
\hline 1 & $\begin{array}{l}\text { I think what we learned in the } \\
\text { Ethics Lecture is important. }\end{array}$ & 8 & 16 & 0 & 1 & 0 & 25 \\
\hline 2 & $\begin{array}{l}\text { Understanding Engineering } \\
\text { Ethics is important to me. }\end{array}$ & 10 & 11 & 4 & 0 & 0 & 25 \\
\hline 3 & $\begin{array}{l}\text { I think what we studied in the } \\
\text { Ethics Lecture is useful for me to } \\
\text { know. }\end{array}$ & 11 & 12 & 1 & 0 & 1 & 25 \\
\hline 4 & $\begin{array}{l}\text { To be honest, I just don't find } \\
\text { Engineering Ethics interesting. } \\
\text { (reversed) }\end{array}$ & 1 & 0 & 6 & 15 & 3 & 25 \\
\hline
\end{tabular}




\begin{tabular}{l|lrrrrrr}
5 & $\begin{array}{l}\text { I think the field of Engineering } \\
\text { Ethics is important. }\end{array}$ & 13 & 11 & 1 & 0 & 0 & 25 \\
6 & $\begin{array}{l}\text { I find the content of the Ethics } \\
\text { Lecture personally meaningful. }\end{array}$ & 5 & 14 & 5 & 1 & 0 & 25 \\
7 & 11 & 8 & 5 & 1 & 0 & 25 \\
8 & $\begin{array}{l}\text { I think this class is interesting. } \\
\text { I see how I can apply what we } \\
\text { learned in the Ethics Lecture to } \\
\text { real life. }\end{array}$ & 11 & 12 & 1 & 1 & 0 & 25
\end{tabular}

\begin{tabular}{|c|c|c|c|c|c|c|c|}
\hline \# & Question & $\begin{array}{l}\text { Strongly } \\
\text { Agree }\end{array}$ & Agree & Neutral & Disagree & $\begin{array}{l}\text { Strongly } \\
\text { Disagree }\end{array}$ & Total \\
\hline 1 & $\begin{array}{l}\text { I think what we learned in the } \\
\text { Ethics Lecture is important. }\end{array}$ & 6 & 2 & 0 & 1 & 0 & 9 \\
\hline 2 & $\begin{array}{l}\text { Understanding Engineering } \\
\text { Ethics is important to me. }\end{array}$ & 5 & 4 & 0 & 0 & 0 & 9 \\
\hline 3 & $\begin{array}{l}\text { I think what we studied in the } \\
\text { Ethics Lecture is useful for me to } \\
\text { know. }\end{array}$ & 4 & 4 & 0 & 1 & 0 & 9 \\
\hline 4 & $\begin{array}{l}\text { To be honest, I just don't find } \\
\text { Engineering Ethics interesting. } \\
\text { (reversed) }\end{array}$ & 0 & 1 & 2 & 4 & 2 & 9 \\
\hline 5 & $\begin{array}{l}\text { I think the field of Engineering } \\
\text { Ethics is important. }\end{array}$ & 4 & 5 & 0 & 0 & 0 & 9 \\
\hline 6 & $\begin{array}{l}\text { I find the content of the Ethics } \\
\text { Lecture personally meaningful. }\end{array}$ & 5 & 3 & 0 & 1 & 0 & 9 \\
\hline 7 & I think this class is interesting. & 5 & 3 & 0 & 1 & 0 & 9 \\
\hline 8 & $\begin{array}{l}\text { I see how I can apply what we } \\
\text { learned in the Ethics Lecture to } \\
\text { real life. }\end{array}$ & 2 & 7 & 0 & 0 & 0 & 9 \\
\hline
\end{tabular}

\section{Instructor 5}

\begin{tabular}{l|lrrrrrr}
$\#$ & Question & $\begin{array}{c}\text { Strongly } \\
\text { Agree }\end{array}$ & Agree & Neutral & $\begin{array}{c}\text { Disagree } \\
\text { Strongly } \\
\text { Disagree }\end{array}$ & Total \\
\hline 1 & $\begin{array}{l}\text { I think what we learned in the } \\
\text { Ethics Lecture is important. }\end{array}$ & 5 & 9 & 1 & 0 & 1 & 16 \\
2 & $\begin{array}{l}\text { Understanding Engineering } \\
\text { Ethics is important to me. }\end{array}$ & 7 & 8 & 1 & 0 & 0 & 16
\end{tabular}


3 I think what we studied in the

5

Ethics Lecture is useful for me to know.

4 To be honest, I just don't find

Engineering Ethics interesting. (reversed)

5 I think the field of Engineering Ethics is important.

6 I find the content of the Ethics Lecture personally meaningful.

7 I think this class is interesting.

8 I see how I can apply what we learned in the Ethics Lecture to real life.

$\begin{array}{llllll}0 & 3 & 0 & 7 & 6 & 16\end{array}$

$\begin{array}{llllll}9 & 6 & 1 & 0 & 0 & 16\end{array}$

$\begin{array}{llllll}6 & 8 & 1 & 1 & 0 & 16\end{array}$

$\begin{array}{llllll}5 & 8 & 2 & 1 & 0 & 16\end{array}$

$\begin{array}{llllll}6 & 6 & 2 & 2 & 0 & 16\end{array}$

